\title{
Performance and digestibility of steers fed by-product of fresh passion fruit or sorghum silage, with and without concentrate supplementation
}

\section{Guilherme Ribeiro Alves ${ }^{1}$, Carlos Augusto de Alencar Fontes ${ }^{2}$, Elizabeth Fonsêca Processi ${ }^{3}$, Alberto Magno Fernandes ${ }^{2}$, Tadeu Silva de Oliveira ${ }^{3}$, Leonardo Siqueira Glória ${ }^{3}$}

\author{
${ }^{1}$ Universidade Federal de Mato Grosso, Departamento de Zootecnia, Rondonópolis, MT, Brasil. \\ ${ }^{2}$ Universidade Estadual do Norte Fluminense Darcy Ribeiro, Laboratório de Zootecnia, Campos dos Goytacazes, RJ, Brasil. \\ ${ }^{3}$ Universidade Estadual do Norte Fluminense Darcy Ribeiro, Programa de Pós-graduação em Ciência Animal, Campos dos Goytacazes, RJ, Brasil.
}

\begin{abstract}
The objective of this study was to evaluate the nutritive value of passion fruit by-product for cattle, contrasting the results with those found with sorghum silage. Four treatments were then constituted, comprising the combinations of the two roughages and the two levels of supplementation (with or without), in a completely randomized design with four animals per treatment. The considered variables included: feed intake, digestibility coefficients of the diets, and live weight gain of the animals. The experimental period lasted 70 days, preceded by a standardization period of 30 days. Chromium oxide was utilized to estimate the fecal output, in the digestibility trial. Treatments were compared by means of three orthogonal contrasts: between the two roughages and between the two concentrate levels within each roughage. Animals fed passion fruit by-product showed higher feed intake (total, per $100 \mathrm{~kg}$ of live weight (TLW), and per unit metabolic size) and had higher TLW gain than those fed sorghum silage (1.304 kg vs. $0.134 \mathrm{~kg}$ ). The coefficients of apparent digestibility of dry matter (DM), organic matter $(\mathrm{OM})$, and crude protein $(\mathrm{CP})$ and the digestibility coefficient of neutral detergent fiber from passion fruit by-product were high, and much higher than those from sorghum silage. The concentrate supplement did not improve the TLW gain of animals fed passion fruit by-product and had a limiting effect on the digestibility coefficients of the diet. The concentrate supplement had a positive associative effect on intake and digestibility coefficients of DM, OM, and CP from sorghum silage. The by-product of fresh passion fruit is an excellent food for growing cattle as it provides high intake levels and weight gains, even when supplied as the only feed.
\end{abstract}

Key Words: byproduct, positive associative effect, reduction of digestibility, weight gain

\section{Introduction}

Brazil is ranked among the three largest fruit producers in the world, after India and China, which, together, account for $43.6 \%$ of the global production. Fruit growing in Brazil represents $11.5 \%$ of the agricultural gross domestic product (GDP), and $0.625 \%$ of the national GDP (MAPA, 2007). Passion fruit (Passiflora edulis) is a culture under rapid expansion for production of both fruit as is and juice. Brazil is the leading passion fruit producer of the world, wherein Bahia is its largest producing state, with approximately 461,000 t (MAPA, 2007).

However, fruit by-products, originating from the making of juices and pulps, do not have a defined market for their commercialization. Besides, they are produced on

Received March 4, 2015 and accepted June 10, 2015

Corresponding author: alberto@uenf.br

http://dx.doi.org/10.1590/S1806-92902015000900002

Copyright (C) 2015 Sociedade Brasileira de Zootecnia. This is an Open Access article distributed under the terms of the Creative Commons Attribution License (http://creativecommons.org/licenses/by/4.0/), which permits unrestricted use, distribution, and reproduction in any medium, provided the original work is properly cited. a large scale at certain times of the year, since this industry is bound to the season harvest (Jobim et al., 2006).

In spite of the optimistic growth of Brazil's agribusiness and its importance to the Brazilian economy, the quality and diversity of generated agricultural and agro-industrial byproducts are a concern because their volume is proportional to the agribusiness growth. Ruminants play a valuable role in sustainable agricultural systems since they are capable of converting renewable natural resources, such as agricultural and agro-industrial by-products, into high-quality feed for men (Oltjen and Beckett, 1996). The use of agro-industrial by-products in animal feeding is an alternative to reduce production costs on farms, as they are a source of nutrients for animals in their natural form or after processing. The use of alternative, non-traditional sources may contribute to covering forage shortage periods and allowing animals to better express their genetic potential.

The passion fruit by-product consists of its peel, pulp, and seeds. The peel represents approximately $62.10 \%$ of the fruit, and is rich in pectin and minerals. The seeds, in turn, are a source of oil with a great potential for use in animal feeding. Pectin is associated with the cell wall, but is not linked covalently to the lignified portions, and 
it is almost entirely digested (90-100\%) in the rumen (Van Soest, 1994).

However, by-products in the processing of tropical fruits and other products in the feeding of ruminants are still used empirically, and hence the great need for experiments aimed at evaluating aspects such as intake, digestibility, and animal performance.

Thus, the objective was to evaluate the effects of including the by-product of fresh passion fruit as a source of roughage, with or without association with concentrate, in diets for Nellore steers on intake, digestibility, and weight gain.

\section{Material and Methods}

The present study was conducted in Campos dos Goytacazes-RJ, Brazil (21 ${ }^{\circ} 44^{\prime} 47^{\prime \prime}$ latitude and $41^{\circ} 18^{\prime} 24^{\prime \prime}$ longitude). The annual maximum and minimum average temperatures in the region are 27.1 and $21.4^{\circ} \mathrm{C}$, respectively, and annual precipitation is $1,023 \mathrm{~mm}$. According to Köppen (1948), the region's climate is classified as tropical rainy forest (AM).

Sixteen yearling Nellore steers with an initial body mass (BM) of $200 \pm 30 \mathrm{~kg}$ were housed in individual, partially covered stalls with cemented floor provided with masonry feeder and individual drinkers. All animals had free access to the mineral mix. The experiment lasted 100 days in total, with 30 days for acclimation, and 70 for the actual experiment.

The experimental design was completely randomized, with four treatments and four replicates, which were arranged as follows: by-product of fresh passion fruit as an exclusive feed; by-product of fresh passion fruit associated with concentrate at the ratio of $0.5 \mathrm{~kg} / 100 \mathrm{BM}$; sorghum silage as exclusive feed; and sorghum silage associated with concentrate at the ratio of $0.5 \mathrm{~kg} / 100 \mathrm{BM}$.

The passion fruit by-product was acquired from the processing industry in intervals of three or four days, remaining piled up at the unloading site, from where it was transported to the animal troughs. The sorghum silage was produced on a soil-surface silo, and the material was cut during the initial grain-forming stage and the culture went through a water shortage period in its initial growth stage.

The passion fruit by-product consisted basically of the peel, although it also contained seeds. The concentrate consisted of $87.5 \%$ ground corn, $2.5 \%$ urea, and $10 \%$ soybean meal (Table 1).

Diets were supplied once daily, in the morning, with the supplied amounts adjusted so as to maintain the individual leftovers at around $10 \%$ of the total supplied. The feed (roughage and concentrate) and leftovers were weighed and sampled daily to determine intake. Samples were conditioned in plastic bags and stored in a freezer at $-15^{\circ} \mathrm{C}$ until the end of the experimental period. After thawing, the composite samples were made and then dried in a forced-ventilation oven at $\pm 55^{\circ} \mathrm{C}$ for $72 \mathrm{~h}$. Subsequently they were processed in a knife mill with $1 \mathrm{~mm}$ sieve and stored in glass bottles at room temperature for the laboratory analyses.

The dry matter (DM), crude fat (CF), lignin, and crude protein $(\mathrm{CP})$ contents were determined according to AOAC (1990); and amylase-treated, ash-free neutral detergent fiber (aNDFom), according to Mertens (2002).

The animals were weighed before the feed was supplied (at $07.00 \mathrm{~h}$ ) to determine weight gain, which was calculated as the difference between the final and initial masses.

Intermediary weightings were performed in 14-day intervals throughout the experimental period aiming to monitor the animal performance and identify possible anomalies.

The apparent digestibility coefficients of the ingested feed were determined using the external marker chromium oxide $\left(\mathrm{Cr}_{2} \mathrm{O}_{3}\right)$ to estimate the fecal excretion. Each animal was administered $5 \mathrm{~g}$ of $\mathrm{Cr}_{2} \mathrm{O}_{3}$, orally, in paper cartridges, twice daily (at 07.00 and $15.00 \mathrm{~h}$ ) for 14 days — seven for adaptation, and seven for the actual collection period. After the seventh day of application, the necessary period to stabilize $\mathrm{Cr}_{2} \mathrm{O}_{3}$ in the digesta, samples of feces were collected manually from the animals' rectum at the times $\mathrm{Cr}_{2} \mathrm{O}_{3}$ was administered until the 14th day. Composite samples were made at the end of the collection period per animal for the seven-day collection period. The composite samples were dried in an oven at $\pm 55{ }^{\circ} \mathrm{C}$ for $72 \mathrm{~h}$ and processed for chromium determination, which was achieved by atomic absorption spectrophotometry, after nitric perchloric digestion, according to the methodology described by Kimura and Miller (1957).

The fecal production was estimated by using the formulae below:

$F P(g / d)=$ Cr supplied $(g / d) /$ Concentration of Cr in feces $(g / g D M)$

Table 1 - Mean contents of dry matter (DM), organic matter (OM), crude protein (CP), and neutral detergent fiber (NDF) of the feedstuffs

\begin{tabular}{lcccccc}
\hline \multirow{2}{*}{ Feed } & \multicolumn{2}{c}{$/ \mathrm{kg}$ as fed } & \multicolumn{3}{c}{$\mathrm{g} / \mathrm{kg} \mathrm{DM}$} \\
\cline { 2 - 2 } \cline { 5 - 6 } \cline { 5 - 6 } & $\mathrm{DM}$ & & $\mathrm{OM}$ & $\mathrm{CP}$ & $\mathrm{NDF}$ \\
\hline Concentrate & 878.3 & & 959.5 & 196.0 & 131.1 \\
Passion fruit residue & 173.4 & & 940.3 & 102.4 & 518.5 \\
Sorghum silage & 263.2 & & 937.3 & 55.9 & 649.1 \\
\hline
\end{tabular}




\section{Results}

in which: $\mathrm{FP}=$ fecal production $(\mathrm{g} /$ day $) ; \mathrm{Cr}$ supplied $=$ supplied chromium (g/day); and Concentration of $\mathrm{Cr}$ in feces $=$ Concentration of chromium in the feces $(\mathrm{g} / \mathrm{g} D M)$.

Treatments were interpreted by analysis of variance based on the combination of two factors: type of roughage (passion fruit by-product and sorghum silage) and two levels of supplementation (with and without concentrate). Treatments were compared by orthogonal contrasts using the GLM procedure of SAS (Statistical Analysis System, version 9.0) software, considering a significance level of 0.05 .

The intakes of DM and OM per $100 \mathrm{~kg} \mathrm{BM}$ and per unit of metabolic size $\left(\mathrm{utm}^{-1}\right)$ of the animals fed passion fruit by-product remained high, and much higher $(\mathrm{P}<0.001)$ than the values observed for sorghum silage (Tables 2 and 3).

When the passion fruit by-product was associated with concentrate, at $0.5 \mathrm{~kg} / 100 \mathrm{~kg} \mathrm{BM}$, an average daily concentrate intake of approximately $1.4 \mathrm{~kg}$ was found during the 70 experimental days; the intake of silage as exclusive feed, however, was low (Table 4). Dry matter intake increased $(\mathrm{P}<0.05)$ in the animals fed sorghum associated

Table 2 - P-values of the orthogonal contrasts regarding passion fruit and sorghum silage $(\mathrm{PF} \times \mathrm{SS})$, with vs. without concentrate ${ }^{1}$ within roughage type, for dry matter (DMI), organic matter (OMI), crude protein (CPI), and neutral detergent fiber (NDFI) intake rates

\begin{tabular}{lccc}
\hline & & & Roughage \\
\cline { 3 - 4 } Variable & PF $\times$ SS & Passion fruit residue & Sorghum silage \\
\cline { 3 - 4 } DMI $^{2}$ & $<0.0001$ & Without concentrate $\times$ With concentrate & Without concentrate $\times$ With concentrate \\
OMI & $<0.0001$ & 0.3147 & 0.0136 \\
CPI & $<0.0001$ & 0.3102 & 0.0134 \\
NDFI & 0.0017 & 0.0657 & 0.0087 \\
& & 0.5076 & 0.0970 \\
DMI & & & 0.0178 \\
OMI & 0.0002 & 0.4250 & 0.0176 \\
CPI & 0.0002 & 0.4215 & 0.0030 \\
NDFI & $<0.0001$ & 0.0614 & 0.3903 \\
DMI & 0.0339 & 0.2596 & 0.0114 \\
OMI & & & 0.0112 \\
CPI & $<0.0001$ & 0.3691 & 0.0027 \\
NDFI & $<0.0001$ & 0.3652 & 0.2344 \\
\hline
\end{tabular}

${ }^{1}$ Concentrate composition: $875 \mathrm{~g} / \mathrm{kg}$ of ground corn, $25 \mathrm{~g} / \mathrm{kg}$ of urea, and $100 \mathrm{~g} / \mathrm{kg}$ of soybean meal.

${ }^{2}$ Absolute intake rate of the nutrient, $\mathrm{kg} \mathrm{day}^{-1}$.

${ }^{3}$ Relative intake rate scaled to $100 \mathrm{~kg}$ of body weight, $0.01 \mathrm{~kg} \mathrm{day}^{-1} \mathrm{~kg}^{-1}$.

${ }^{4}$ Relative intake rate scaled to metabolic body size, $\mathrm{kg}$ day ${ }^{-1} \mathrm{~kg}^{-0.75}$.

Table 3 - Means and coefficient of variation (CV) for dry matter (DMI), organic matter (OMI), crude protein (CPI), and neutral detergent fiber (NDFI) intake rates

\begin{tabular}{|c|c|c|c|c|c|c|c|}
\hline \multirow{3}{*}{ Variable } & \multirow{3}{*}{$\mathrm{PF}$} & \multirow{3}{*}{ SS } & \multicolumn{4}{|c|}{ Roughage } & \multirow{3}{*}{$\mathrm{CV}, \%$} \\
\hline & & & \multicolumn{2}{|c|}{ Passion fruit residue } & \multicolumn{2}{|c|}{ Sorghum silage } & \\
\hline & & & Without/Conc & With/Conc & Without/Conc & With/Conc & \\
\hline $\mathrm{DMI}^{1}$ & 6.07 & 3.77 & 5.77 & 6.36 & 2.97 & 4.57 & 15.93 \\
\hline OMI & 5.77 & 3.57 & 5.49 & 6.05 & 2.81 & 4.33 & 15.89 \\
\hline CPI & 0.63 & 0.26 & 0.58 & 0.69 & 0.17 & 0.35 & 18.15 \\
\hline NDFI & 2.87 & 2.12 & 2.97 & 2.78 & 1.88 & 2.36 & 15.07 \\
\hline $\mathrm{DMI}^{2}$ & 2.60 & 1.88 & 2.52 & 2.68 & 1.61 & 2.15 & 12.42 \\
\hline OMI & 2.47 & 1.78 & 2.39 & 2.55 & 1.53 & 2.04 & 12.43 \\
\hline CPI & 0.27 & 0.13 & 0.25 & 0.29 & 0.09 & 0.16 & 13.81 \\
\hline NDFI & 1.23 & 1.07 & 1.29 & 1.18 & 1.02 & 1.11 & 12.23 \\
\hline $\mathrm{DMI}^{3}$ & 101.53 & 70.76 & 97.97 & 105.09 & 59.37 & 82.14 & 12.52 \\
\hline OMI & 96.55 & 67.04 & 93.15 & 99.96 & 56.21 & 77.87 & 12.52 \\
\hline CPI & 10.59 & 4.80 & 9.77 & 11.42 & 3.36 & 6.24 & 14.02 \\
\hline NDFI & 48.18 & 39.98 & 50.30 & 46.06 & 37.60 & 42.36 & 12.22 \\
\hline
\end{tabular}

${ }^{1}$ Absolute intake rate of the nutrient, $\mathrm{kg} \mathrm{day}^{-1}$.

${ }^{2}$ Relative intake rate scaled to $100 \mathrm{~kg}$ of body weight, $0.01 \mathrm{~kg} \mathrm{day}^{-1} \mathrm{~kg}^{-1}$.

${ }^{3}$ Relative intake rate scaled to metabolic body size, $\mathrm{kg}^{-1 a y^{-1}} \mathrm{~kg}^{-0.75}$. 
with concentrate at $0.5 \mathrm{~kg} / 100 \mathrm{~kg} \mathrm{BM}$. In this treatment, in addition to consuming around $1.0 \mathrm{~kg}$ concentrate, the animals ingested $0.6 \mathrm{~kg}$ more silage DM $(\mathrm{P}<0.05)$ than the animals that did not receive any supplement, which was a $20 \%$ increase (Tables 2 and 3 ).

The animals fed passion fruit by-product had a greater $(\mathrm{P}<0.05)$ intake of NDF per $100 \mathrm{~kg} \mathrm{BM}$ as compared with those fed sorghum silage (Tables 2 and 3 ).

The diets containing passion fruit by-product showed higher digestibility coefficients $(\mathrm{P}<0.001)$ of $\mathrm{DM}, \mathrm{OM}, \mathrm{CP}$, and NDF than those containing sorghum silage (Tables 4 and 5).

The combination of concentrate with sorghum silage provided an increase $(\mathrm{P}<0.05)$ in the digestibility of $\mathrm{DM}$, $\mathrm{OM}$, and $\mathrm{CP}$, but did not increase significantly $(\mathrm{P}>0.05)$ the digestibility of NDF (Tables 4 and 5).

Concerning the passion fruit by-product, a decrease $(\mathrm{P}<0.05)$ in the digestibility of DM, OM, CP, and NDF was observed when it was associated with concentrate at the level of approximately $1.5 \mathrm{~kg} /$ animal day ${ }^{-1}$ (Tables 4 and 5).

The crude protein from the sorghum silage showed extremely low apparent digestibility coefficients, which were even lower when it was associated with concentrate (Tables 4 and 5). These low apparent digestibility values are a result of the low intake of protein by these animals (Tables 2 and 3), which makes the fecal metabolic protein excretion represent a high proportion of the excreted protein, thus markedly interfering with the digestibility coefficient of the CP.

The animals that received passion fruit by-product had much greater gains in body mass $(\mathrm{P}<0.001)$ than those fed sorghum silage (Table 6). No statistical difference $(\mathrm{P}>0.05)$ was observed among the animals fed passion fruit by-product or among those fed sorghum silage (Table 6).

Table 4 - P-values of the orthogonal contrasts regarding passion fruit and sorghum silage $(\mathrm{PF} \times \mathrm{SS})$, with vs. without concentrate within roughage type, for dry matter (DDM), organic matter (DOM), crude protein (DCP), and neutral detergent fiber (DNDF) digestibilities (g/kg DM)

\begin{tabular}{lccc}
\hline & & \multicolumn{2}{c}{ Roughage } \\
\cline { 3 - 4 } Variable & PF $\times$ SS & Passion fruit residue & Sorghum silage \\
\cline { 3 - 3 } & & Without concentrate $\times$ With concentrate & Without concentrate $\times$ With concentrate \\
\hline DDM & $<0.0001$ & 0.0404 & 0.0139 \\
DOM & $<0.0001$ & 0.0385 & 0.0309 \\
DCP & $<0.0001$ & 0.0482 & 0.0002 \\
DNDF & $<0.0001$ & 0.0056 & 0.5924 \\
\hline
\end{tabular}

Table 5 - Means and coefficients of variation (CV) regarding passion fruit (PF) and sorghum silage (SS), with vs. without concentrate within roughage type, for dry matter (DDM), organic matter (DOM), crude protein (DCP), and neutral detergent fiber (DNDF) digestibilities $(\mathrm{g} / \mathrm{kg} \mathrm{DM})$

\begin{tabular}{|c|c|c|c|c|c|c|c|}
\hline \multirow{3}{*}{ Variable } & \multirow{3}{*}{ PF } & \multirow{3}{*}{ SS } & \multicolumn{4}{|c|}{ Roughage } & \multirow{3}{*}{$\mathrm{CV}, \%$} \\
\hline & & & \multicolumn{2}{|c|}{ Passion fruit residue } & \multicolumn{2}{|c|}{ Sorghum silage } & \\
\hline & & & Without/Conc & With/Conc & Without/Conc & With/Conc & \\
\hline DDM & 708.2 & 361.7 & 755.2 & 661.1 & 302.8 & 420.6 & 10.83 \\
\hline DOM & 707.0 & 425.0 & 753.4 & 660.5 & 376.2 & 473.9 & 9.98 \\
\hline DCP & 675.9 & 183.6 & 725.3 & 626.5 & 65.0 & 302.2 & 14.79 \\
\hline DNDF & 538.6 & 256.2 & 658.1 & 419.1 & 236.7 & 275.7 & 25.23 \\
\hline
\end{tabular}

Table 6 - P-values of the orthogonal contrasts regarding passion fruit (PF) and sorghum silage (SS), with vs. without concentrate within roughage type, for the average daily gain $\left(\mathrm{ADG}, \mathrm{g}\right.$ day $\left.{ }^{-1}\right)$, and means and coefficients of variation $(\mathrm{CV})$ for $\mathrm{ADG}$ by animals fed diets with and without concentrate per roughage type

\begin{tabular}{|c|c|c|c|c|c|c|c|}
\hline \multirow{3}{*}{ Variable } & \multirow{3}{*}{$\mathrm{PF}$} & \multirow{3}{*}{ SS } & \multicolumn{4}{|c|}{ Roughage } & \multirow{3}{*}{$\mathrm{CV}, \%$} \\
\hline & & & \multicolumn{2}{|c|}{ Passion fruit residue } & \multicolumn{2}{|c|}{ Sorghum silage } & \\
\hline & & & Without/Conc & With/Conc & Without/Conc & With/Conc & \\
\hline
\end{tabular}




\section{Discussion}

The intake of passion fruit by-product apparently was not affected because it remained piled in fresh form for three to four days, after it was obtained from the factory. The observed high intakes of DM from the by-product were possibly a result of its appropriate $\mathrm{CP}$ content and high digestibility rates. However, the moisture content of the feed may influence its consumption, since the NRC (2001) presents results that indicate elevation in DM intake as the moisture content of the feed is reduced. The high moisture of the fresh by-product may be the factor responsible for the lower intake values found in the present study as compared with those obtained by Vieira (1997), who worked with dried and ground passion fruit by-product and reported an intake of $3.29 \%$ BM or $156.11 \mathrm{~g} \mathrm{utm}^{-1}$.

The association of the passion fruit by-product with the concentrate resulting in a $0.56 \mathrm{~kg}$ increase in daily DM intake characterized a substitutive effect of the concentrate. Minson (1990) presented results showing that as the forage $\mathrm{CP}$ content is reduced there is an increase in the coefficient of substitution of forage for concentrate, and mentioned a coefficient of substitution of $44 \%$ for forages with a CP content between 7 and 14\%.

The sorghum silage used in the present study contained $55.9 \mathrm{~g} \mathrm{~kg}^{-1}$ CP. According to Minson (1990), when the forage contains less than $62 \mathrm{~g} \mathrm{~kg}^{-1} \mathrm{CP}$, the fiber digestion is inhibited. The same author also presents results of a number of experiments that showed an increase of 14 to $77 \%$ in DM intake after the supply of protein supplements. This fact is evident in the present study, which clearly shows an associative effect of the utilized supplement, with $196 \mathrm{~g} \mathrm{~kg}^{-1}$ $\mathrm{CP}$ and the silage. When animals received $1 \mathrm{~kg}$ concentrate with $196 \mathrm{~g} \mathrm{~kg}^{-1} \mathrm{CP}$ and consumed $3.57 \mathrm{~kg}$ sorghum silage, with $55.6 \mathrm{~g} \mathrm{~kg}^{-1} \mathrm{CP}$, their diet had a CP content of $85 \mathrm{~g} \mathrm{~kg}^{-1}$. These results denote an associative effect of the protein supplement, similar to the results reported by Pimentel et al. (1998), who observed a $23.45 \%$ increase in sorghum intake by cattle when the silage was supplemented with soybean meal at the proportion of $20 \%$ of DM.

Similarly, an associative effect between concentrate and sorghum silage was found on the intakes of OM, NDF, and CP. In addition to the lower CP content, the lower intake of sorghum silage might have partly resulted from the presence of fermentation end products present in the silage that, according to NRC (2001), reduce intake.

The intake of NDF from the passion fruit by-product was close to the threshold of $12.0 \pm 1.0 \mathrm{~g} / \mathrm{kg} \mathrm{BM}$ proposed by Mertens (1992) as the maximum level of NDF intake, in conditions in which the physical rumen fill is the regulatory mechanism of voluntary intake. However, Detmann et al. (2003) claimed that estimates higher than $12 \mathrm{~g} / \mathrm{kg} \mathrm{BM}$ are commonly observed in tropical conditions, attributed to differences in the ruminal dynamics of the fibrous fraction, especially regarding the indigestible NDF fraction. The variation in NDF intake may be attributed to the nature of the fiber, as it can be influenced by the proportions of each component of the cell wall, which can alter the digestibility and thus affect the intake of this nutrient (NRC, 2001; Lousada Jr. et al., 2005).

The digestibility of the roughages partly explains the marked differences in their intake, since the carbohydrate fermentation rate is one of the determinants of voluntary intake in ruminants (Balch and Campling, 1962). High digestibility coefficients in passion fruit by-product were also observed by Lousada Jr. et al. (2005) and Azevêdo et al. (2011). Working with sheep fed silages containing increasing proportions of passion fruit by-product and elephant grass, Reis et al. (2000) observed a linear decline in the digestibility of DM, CP, and NDF from the silages as the level of by-product in the mix was reduced.

In addition to the inclusion of more digestible carbohydrates in the diet, with association of concentrate, which would typically elevate the average digestibility, a positive associative effect apparently also occurred when the supply of protein to ruminal microorganisms was increased.

The passion fruit by-product had a relatively elevated $\mathrm{CP}$ content (102.4 $\mathrm{g} \mathrm{kg}^{-1}$ ), and consequently the protein supply would not be a limiting factor to the action of ruminal microorganisms. Besides, the passion fruit byproduct contains high levels of pectin (Ariki et al., 1977), a rapid-degradation carbohydrate, which explains the high digestibility coefficients of $\mathrm{DM}, \mathrm{OM}, \mathrm{CP}$, and NDF, when supplied as the exclusive feed. In this case, the association with concentrate probably reduced the digestibility of the fiber fraction of the roughage. The greater supply of nonfiber carbohydrates may reduce the fiber digestion by its inhibitory effect on cellulolysis or by inhibiting the sites of enzymatic digestion in the fibers, according to Terry et al. (1969) and Murphy (1989).

The animals fed unsupplemented sorghum silage ingested, on average, only $166 \mathrm{~g} \mathrm{~kg}^{-1} \mathrm{CP}$ daily. The observed fecal excretion was $155.2 \mathrm{~g} \mathrm{~kg}^{-1}$ per day. Using the ratio adopted by the NRC (1985), which estimates an excretion of metabolic fecal protein (MFP) of $90 \mathrm{~g} \mathrm{~kg}^{-1}$ of indigestible DM ingested, these animals would have a MFP excretion of $186 \mathrm{~g} \mathrm{~kg}^{-1}$. Subtracting this MFP value from the observed fecal excretion of $\mathrm{CP}$ would result in a CP true digestibility greater than $100 \%$. These animals 
lost approximately $80 \mathrm{~g}$ of BM daily, using body protein to meet part of their maintenance requirements. Besides, as shown by Hoog (1991) in a review, when animals go into a process of weight loss, their plasma growth-hormone level is increased, which elevates the body lipolysis, consequently reducing the degradation of the body protein, which thus reduces the mobility of amino acids to energy production, and this may have an effect on the excretion of MFP.

Using the same calculations above for animals receiving sorghum silage and concentrate supplement, whose observed apparent CP digestibility value was $302.2 \mathrm{~g} \mathrm{~kg}^{-1}$, we obtain a CP intake of $388.4 \mathrm{~g} \mathrm{~kg}^{-1}$ day. The measured fecal excretion was $271.14 \mathrm{~g} \mathrm{~kg}^{-1}$. The fecal excretion of MFP calculated by using the ratio proposed by NRC (1985) would be $238.3 \mathrm{~g} \mathrm{~kg}^{-1}$, which, after subtracting $271.14 \mathrm{~g} \mathrm{~kg}^{-1}$, would result in an estimated CP true digestibility of $91.5 \%$.

The same calculations, performed for the passion fruit by-product, resulted in estimated $\mathrm{CP}$ true digestibility values of 94.0 and $90.86 \%$ for the by-product used exclusively and as a supplemented, respectively.

Literature results by Siqueira et al. (1998) show a weight gain of $1.357 \mathrm{~kg}$ day $^{-1}$ in $\mathrm{F}_{1}$ Angus-Nellore animals fed a diet containing $50 \%$ silage of passion fruit by-product and $50 \%$ concentrate. The comparison between experiments is hindered by the greater proportion of concentrates in the diet utilized by the aforementioned authors and because they utilized animals with an initial BM of $400 \mathrm{~kg}$, which therefore had higher energy requirements per kilogram than the animals from the present study, whose body mass was $200 \mathrm{~kg}$, due to the change in the composition of gain, which occurs as BM is elevated, as stated by Fontes (1995).

The dietary supplementation with concentrate to the cattle, at the level of $0.5 \% \mathrm{BM}$, had no influence $(\mathrm{P}>0.05)$ on the gain of the animals receiving passion fruit by-product. In those, as discussed previously, supplementation with concentrate, at around $1.2 \mathrm{~kg}$ animal $\mathrm{day}^{-1}$, on average, resulted in an increase of 0.59 in DM intake only, with the occurrence of a substitutive effect of concentrate, and resulted in a decline in DM digestibility from $755.2 \mathrm{~g} \mathrm{~kg}^{-1}$ to $661.1 \mathrm{~g} \mathrm{~kg}^{-1}$. The reduction observed in the DM intake from the passion fruit by-product, at around $0.6 \mathrm{~kg}$, in supplemented animals, and the reduced digestibility of the total dietary DM, may explain the low average increase of only $70 \mathrm{~g}$ in the animals' mass gain.

The animals fed sorghum silage without supplement had a body mass loss of $80 \mathrm{~g}$ per day. This mass bay be partly explained by the low protein content of the sorghum silage, $55.9 \mathrm{~g} \mathrm{~kg}^{-1}$ in DM. Minson (1990) observed that the fiber digestion was inhibited in feeds with a $\mathrm{CP}$ content below $62 \mathrm{~g} \mathrm{~kg}^{-1}$ in DM. This author also reported that a large number of experiments evaluating the intake of forages showed that protein supplementation elevated forage intake from 14 to $77 \mathrm{~g} \mathrm{~kg}^{-1}$.

The low DM intake by the animals fed sorghum silage exclusively and the decline in the feed digestibility explain their low performance.

The animals fed the sorghum silage, with $55.9 \mathrm{~g} \mathrm{~kg}^{-1}$ $\mathrm{CP}$, with addition of approximately $1 \mathrm{~kg}$ of concentrate supplement, with $190 \mathrm{~g} \mathrm{~kg}^{-1} \mathrm{CP}$, ingested a diet with around $85 \mathrm{~g} \mathrm{~kg}^{-1} \mathrm{CP}$. In this case, an associative effect of concentrate was observed as the sorghum silage intake was increased, as discussed previously, which resulted in a daily DM intake of $4.57 \mathrm{~kg}$. This fact and the increase observed in the digestibility of OM (473.9 $\mathrm{g} \mathrm{kg}^{-1}$ for supplemented silage vs. $376.2 \mathrm{~g} \mathrm{~kg}^{-1}$ for silage unassociated with concentrate) provided the average daily gain of $0.35 \mathrm{~kg}$ by these animals.

\section{Conclusions}

Passion fruit by-product provides high intake levels, high digestibility coefficients of dry matter, organic matter, crude protein and neutral detergent fiber, and high weight gains, which are all much higher than those observed with the sorghum silage.

Supplementation with concentrate containing $19 \mathrm{~g} \mathrm{~kg}^{-1}$ crude protein at the level of $0.5 \%$ of the body mass reduces the digestibility of the diet containing passion fruit byproduct, and has a negative associative effect on the intake of the by-product. As a result, the increase provided in mass gain is not very expressive.

The concentrate has a positive associative effect on the intake and digestibility of the sorghum silage, resulting in increased animal weight gain.

\section{References}

AOAC - Association of Official Analytical Chemists. 1990. Official methods of analysis. 15th ed. AOAC, Arlington, VA.

Ariki, J.; Toledo, P. R.; Ruggiero, C. and Oliveira, J. C. 1977. Aproveitamento de cascas desidratadas e sementes de maracujá amarelo (Passiflora edulis f. Flavicarpa Deg.) na alimentação de frangos de corte. Cientifica 3:340-343.

Azevêdo, J. A. G.; Valadares Filho, S. C.; Pina, D. S.; Detmann, E.; Valadares, R. F. D.; Pereira, L. G. R.; Souza, N. K. P. and Silva, L. F. C. 2011. Consumo, digestibilidade total, produção de proteína microbiana e balanço de nitrogênio em dietas com subprodutos de frutas para ruminantes. Revista Brasileira de Zootecnia 40:1052-1060.

Balch, C. C. and Camping, R. C. 1962. Regulation of voluntary intake in ruminants. Nutrition Abstracts Reviews 36:669-686.

Detmann, E.; Queiroz, A. C.; Cecon, P. R.; Zervoudakis, J. T.; Paulino, M. F.; Valadares Filho, S. C.; Cabral, L. S. and Lana, R. P. 2003. Consumo de fibra em detergente neutro por bovinos em confinamento. Revista Brasileira de Zootecnia 32:1763-1777. 
Fontes, C. A. A. 1995. Composição corporal, exigências líquidas de nutrientes para ganho de peso e desempenho produtivo de animais zebuínos e mestiços europeu-zebu. Resultados experimentais. p.419-455. In: Anais do Simpósio Internacional sobre Exigências Nutricionais de Ruminantes. Universidade Federal de Viçosa, Viçosa, MG, Brasil.

Hoog, B. W. 1991. Compensatory growth in ruminants. p.103-134. In: Growth regulation in farm animals. Pearson, A. M. and Dutson, T. R., eds. Elsevier, England.

Jobim, C. C.; Cecato, U.; Branco, A. F. and Bumbieris Junior, V. H. 2006. Subprodutos da agroindústria na alimentação de bovinos. p.329-358. In: Anais do Simpósio sobre Manejo Estratégico da Pastagem. UFV; DZO, Viçosa, MG.

Köeppen, W. 1948. Climatologia. Panamericana, Buenos Aires, Argentina.

Lousada Júnior, J. E.; Neiva, J. N.; Rodriguez, N. M.; Pimentel, J. C. M. and Lôbo, R. N. B. 2005. Consumo e digestibilidade aparente de subprodutos do processamento de frutas em ovinos. Revista Brasileira de Zootecnia 34:659-669.

Kimura, F. T. and Miller, V. L. 1957. Chromic oxide measurement. Improved determination of chromic oxide in cow feed and feces. Journal of Agricultural and Food Chemistry 5:216-216.

Mertens, D. R. 1992. Análise de fibra e sua utilização na avaliação e formulação de rações. p.188-219. In: Anais da 29a Reunião Anual da Sociedade Brasileira de Zootecnia. Sociedade Brasileira de Zootecnia, Lavras.

Mertens, D. R. 2002. Gravimetric determination of amylase-treated neutral detergent fiber in feeds with refluxing in beakers or crucibles: collaborative study. Journal of AOAC International 85:1217-1240.

MAPA - Ministério da Agricultura, Pecuária e Abastecimento. 2007. Cadeia produtiva de frutas. Brasília, Brasil.

Minson, D. J. 1990. Forage in ruminant nutrition. Academic Press, New York.

Murphy, M. 1989. The influence of non-structural carbohydrates on rumen microbes and rumen metabolism in milk producing cows.
Thesis (Ph. D.). Swedish University of Agricultural Sciences, Uppsala, Sweden.

NRC - National Research Council. 1985. Ruminant nitrogen usage. National Academy Press, Washington, D.C.

NRC - National Research Council. 2001. Nutrient requirements of dairy cattle. 7th ed. National Academy Press, Washington, D.C.

Oltjen, J. W. and Beckett, J. L. 1996. Role of ruminant livestock in sustainable agricultural systems. Journal of Animal Science 74:1406-1409.

Pimentel, J. J. O.; Silva, J. F. C.; Valadares Filho, S. C.; Cecon, P. R. and Santos, P. S. 1998. Efeito da suplementação protéica no valor nutritivo de silagens de milho e sorgo. Revista Brasileira de Zootecnia 27:1042-1049.

Reis, J.; Paiva, P. C. A.; Tiesenhausen, I. M. E. V. and Resende, C. A. P. 2000. Composição química, consumo voluntário e digestibilidade de silagens de resíduos do fruto de maracujá (Passiflora edulis Sims f. flavicarpa) e de capim-elefante (Pennisetum purpureum Schum) cv. Cameroon e suas combinações. Ciência e Agrotecnologia 24:213-224.

Siqueira, G. B.; Bertipaglia, L. M. A.; Andrade, P. and Alcalde, C. R. 1998. Utilização do resíduo de maracujá e silagens de híbridos de milho, na terminação de bovinos de corte em confinamento. p.368-370. In: Anais da 35a Reunião Anual da Sociedade Brasileira de Zootecnia. Sociedade Brasileira de Zootecnia, Botucatu.

Terry, R. A.; Tilley, J. M. A. and Outen, G. E. 1969. Effect of pH on cellulose digestion under in vitro conditions. Journal of the Science of Food and Agriculture 20:317-320.

Van Soest, P. J. 1994. Nutritional ecology of the ruminant. 2nd ed. Cornell University Press, New York.

Vieira, C. V. 1997. Análise químico-bromatológica e degradabilidade in situ da matéria seca, proteína bruta e da fibra em detergente neutro do resíduo (casca) de três variedades de maracujá (Passiflora spp). Dissertação (M.Sc.). Universidade Estadual do Norte Fluminense, Campos dos Goytacazes, RJ, Brasil. 